\title{
PHF6 Gene Mutation
}

National Cancer Institute

\section{Source}

National Cancer Institute. PHF6 Gene Mutation. NCI Thesaurus. Code C153270.

A change in the nucleotide sequence of the PHF6 gene. 